\title{
Ultrasonic nebulization-sample introduction system for quantitative analysis of liquid samples by laser-induced breakdown spectroscopy
}

\author{
Nadir Aras, Semira Ünal Yeşiller, Dilek Arıca Ateş, Şerife Yalçın* \\ İzmir Institute of Technology, Faculty of Science, Chemistry Department, 35430 İzmir, Turkey
}

\section{A R T I C L E I N F O}

\section{Article history:}

Received 15 December 2011

Accepted 16 June 2012

Available online 27 June 2012

\section{Keywords:}

Laser-induced breakdown spectroscopy

Ultrasonic nebulization

Metal aerosol

Membrane dryer

\begin{abstract}
A B S T R A C T
In this study, design and optimization studies of a sample introduction system based on ultrasonic nebulization of metal salts in aqueous environment for laser-induced breakdown spectroscopic detection were presented. The system consisted of an ultrasonic nebulizer connected to a tandem heater-condenser-membrane dryer unit that produces sub-micron size aerosols. Results indicate improvements in detection limits for some elements with the use of membrane dryer. Optimization studies were performed by systematical investigation of LIBS emission signal with respect to laser energy, carrier gas flow rate and detector timing parameters. Under optimized conditions, calibration graphs for $\mathrm{Na}, \mathrm{K}, \mathrm{Mg}, \mathrm{Ca}, \mathrm{Cu}, \mathrm{Al}, \mathrm{Cr}, \mathrm{Cd}, \mathrm{Pb}$ and $\mathrm{Zn}$ were constructed and detection limits were calculated. The applicability of the ultrasonic nebulization-LIBS system was tested on real water samples. This system establishes LIBS as an effective analytical tool for both qualitative and quantitative determination of metal aerosols in aqueous environments. This technique is sufficiently rapid to provide real-time monitoring of toxic metals.
\end{abstract}

(C) 2012 Elsevier B.V. All rights reserved.

\section{Introduction}

Sample introduction is one of the most problematical area in liquids analysis by laser-induced breakdown spectroscopy, LIBS. Analyzing elements directly from the bulk liquid $[1,2]$ suffers from difficulties like splashing, bubble formation and shock wave formation after focusing the laser beam on liquids. In order to overcome those difficulties experienced in liquid analysis, plasma formation on liquid surfaces $[3,4]$, on droplets [5,6], on flowing-jet liquids $[7,8]$ and in cavitation bubbles [9] has been employed. Use of double pulses for plasma formation [10-12] has also been realized in liquid analysis by LIBS, with high sensitivity. Aerosol formation by suitable nebulization techniques [13-19] is another approach to liquid analysis by LIBS. Fine aerosol particles of micrometer to nanometer sizes can be obtained by pneumatic, ultrasonic and electrospray nebulization techniques. Studies based on the formation of volatile hydrides of some toxic elements from their solutions before laser-induced breakdown spectroscopic detection in aqueous environments have also been reported [20-22]. The sensitivity of LIBS for quantitative analysis of liquids compared to other atomic emission spectroscopic techniques, such as ICP-AES, is quite low and the limits of detection, (LOD) reported for several elements vary between high $\mathrm{ppb}(\mu \mathrm{g} / \mathrm{L})$ to low ppm(mg/L) levels [4,23-26]. However, LIBS is a very convenient technique to develop portable sensors for detecting and monitoring of environmental pollutants in the field. In order to make LIBS applicable

\footnotetext{
* Corresponding author. Tel.: +90 232 7507624; fax: +90 2327507509.

E-mail address: serifeyalcin@iyte.edu.tr (Ş. Yalçın).
}

to liquid analysis at low concentrations, analytical capabilities of the LIBS technique needs to be improved with serious laboratory efforts.

In this study, a sample introduction system that utilizes ultrasonic nebulization for aerosol generation and a tandem heater-condensermembrane dryer unit for desolvation and drying of aerosols has been realized for fast and sensitive analysis of metal salts present in aqueous environments by laser-induced breakdown spectroscopy. Variations of LIBS signal with respect to laser energy, carrier gas flow rate and detector timing parameters were systematically investigated. The effects of using membrane dryer on LOD values of $\mathrm{Na}, \mathrm{K}, \mathrm{Mg}, \mathrm{Ca}, \mathrm{Cu}$, $\mathrm{Al}, \mathrm{Cr}, \mathrm{Cd}, \mathrm{Pb}$ and $\mathrm{Zn}$ were evaluated. In order to overcome a common problem of plasma movement along the slit width, a telescopic system design that directs the laser beam from the top perpendicular to the sample flow was utilized. This way, plasma movement along the slit height and hence higher probability of obtaining LIBS signal from every single laser shot were achieved.

\section{Experimental}

The experimental set-up for ultrasonic nebulization-LIBS system, schematically shown in Fig. 1, consisted of a sample introduction, plasma formation and detection units. Metal aerosols produced in the sample introduction unit are coupled to a 5 armed teflon plasma cell. Laser pulses of 45-150 mJ energy were focused in the center of a teflon cell from the top arm by means of a $5 \mathrm{~cm}$ focal length lens and meet with a flow of dry aerosols at $90^{\circ}$ angle to form plasma. Plasma emission was collected and spectrally resolved by an echelle type spectrograph and detected by a time gated ICCD detector. The 


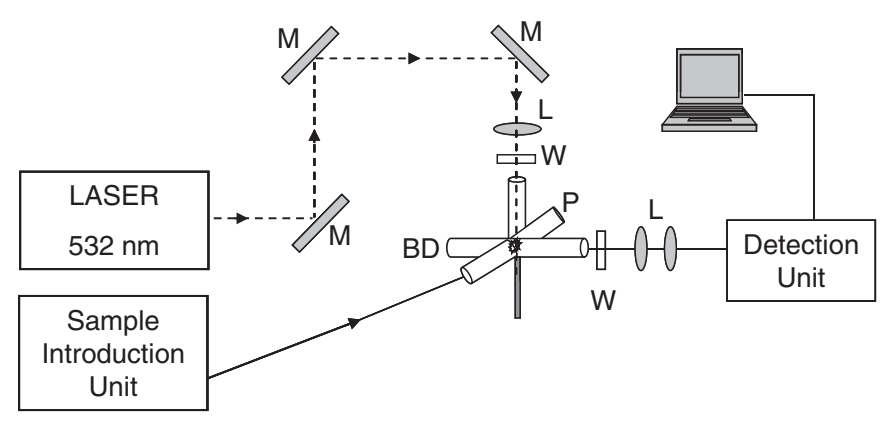

Fig. 1. Experimental LIBS set-up for the analysis of metal aerosols. M: $532 \mathrm{~nm}$ reflective mirrors, L: focusing and collimating lenses, W: quartz windows, P: pump, BD: Beam Dump.

details of each part of the experimental set-up are given in the following sections.

\subsection{Sample introduction unit}

Pictures of the sample introduction system consisting of an ultrasonic nebulizer, USN, desolvation unit and a membrane dryer connected to a teflon plasma cell are given in Fig. 2(a) and (b). Each part is explained below, in detail.

\subsubsection{Ultrasonic nebulizer}

An ultrasonic particle generator (Sonaer, 241PG), Fig. 2(a), with $50 \mathrm{~mL}$ of liquid sample capacity was used for production of micron sized aerosols from aqueous metal solutions. Some amount of liquid sample placed inside the particle generator was first converted into fine aerosol droplets by a piezo-electric crystal that vibrates at a frequency of $2.4 \mathrm{MHz}$. Aerosols generated inside the USN were carried into the desolvation unit by a flow of nitrogen gas at a rate of $3-5 \mathrm{~L} / \mathrm{min}$.

\subsubsection{Desolvation unit}

A compact heater/condenser desolvation unit [14,27], shown in Fig. 2(a), which consisted of heating and condensing tubes was constructed at the local glass shop for the removal of the solvent content of the metal aerosols. This unit was directly placed at the top of the USN and the aerosols formed inside the nebulizer travel through a $20 \mathrm{~cm}$ long glass tube placed on top of the nebulizer exit. Three meter long heating tape (Cole-Palmer), wrapped around this glass tube keeps the inside temperature of the tube around $110^{\circ} \mathrm{C}$. At this temperature, hot aerosols move through a $15 \mathrm{~cm}$ long condenser unit in which cooled water at $4{ }^{\circ} \mathrm{C}$ circulates outside (PolyScience). Here, the evaporated solvent condenses and is collected (drain) at the bottom end of the unit, while dry aerosols travel through the membrane dryer unit. The solvent removal efficiency of the desolvation unit has been tested via Atomic Absorption Spectrometric measurements of the drain solution. It has been found that $90 \%$ of the analyte solution is transported to the sample cell while $10 \%$ is lost to the drain during the desolvation process.

\subsubsection{Membrane dryer}

After passing the desolvation unit, dry aerosols travel through a naphion membrane dryer (Perma Pure, PD50), Fig. 2(a) and (b), for the removal of their excess moisture. Here, the aerosols flow within the nafion tubes while water vapor is carried away by a dry purge gas flowing over the exterior surface of the membrane tubing in counter-current direction with respect to the sample flow. Nitrogen gas flowing at flow rates smaller than the sample flow rate (typically $3.5 \mathrm{~L} / \mathrm{min}$ ) was used as a purge gas. The effect of membrane dryer on LIBS signal intensity is discussed in the Results and discussion section below. After passing the drying unit, aerosols are introduced into the sample/plasma cell from one side arm of the cell for plasma formation.

\subsubsection{Teflon cell}

The sample/plasma cell, Fig. 2(b), with five arms, each $5 \mathrm{~cm}$ length and $1 \mathrm{in}$. outer diameter, was machined from the teflon material in local machine shop and has been used previously [20] in another LIBS application of our group. The arms at which laser beam entering and plasma emission to be collected were covered with quartz windows. The medium inside the cell has been kept uniformly flowing using a vacuum pump (Edwards), connected to a third arm of the sample cell. It should be noted that the system was under atmospheric pressure due to the continuous nebulization of the sample during experiments. The aerosols were introduced into the sample/plasma cell from the one side arm of the cell and the remaining arm was blocked by a beam dump.

\subsection{Plasma formation}

A Q-switched Nd:YAG laser, (Quanta-Ray, Lab 170, Spectra Physics), working at the second harmonic wavelength, $532 \mathrm{~nm}$, with $10 \mathrm{~ns}$ pulse duration and $10 \mathrm{~Hz}$ repetition rate was used for plasma formation. In order to overcome a common problem of plasma movement along the slit width, a telescopic system design, as shown in Fig. 1, was used. Here, three highly reflective mirrors placed successively at $45^{\circ}$ angle with respect to incoming laser beam were used to direct laser beam from the top arm of the sample cell, perpendicular to the sample flow. This design enables plasma movement from one laser
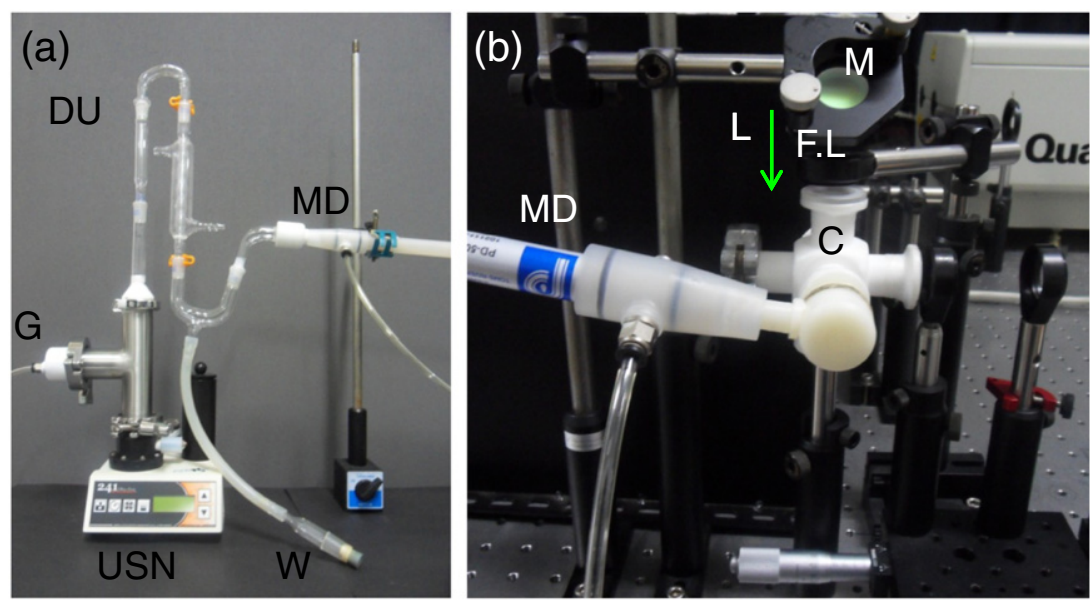

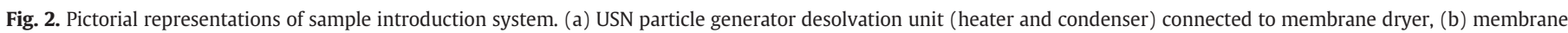

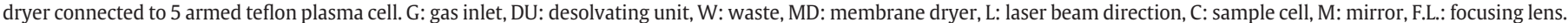


shot to another along the slit height, as is shown in Fig. 3, and hence plasma emission from most of the laser pulses is recorded.

A $5 \mathrm{~cm}$ focal length and $1 \mathrm{in}$. diameter lens was used to focus the laser beam between 20 and $150 \mathrm{~mJ}$ pulse energies down to $5 \mu \mathrm{m}$ of a spot size. This would corresponds to $1.0 * 10^{13} \mathrm{~W} / \mathrm{cm}^{2}-7.6 * 10^{13} \mathrm{~W} / \mathrm{cm}^{2}$ irradiances for plasma formation and laser energy measurements were performed by a power/energy meter (Ophir, Nova II).

\subsection{Detection of the optical emission}

Laser-induced breakdown emission from the metal aerosols was collected and imaged by using two plano-convex lenses of $5 \mathrm{~cm}$ and $17.5 \mathrm{~cm}$ focal length onto the entrance slit of an echelle type spectrograph (ME5000, Andor Inc. $f=195 \mathrm{~mm}$ ), that is coupled to an image intensified charge coupled detector, ICCD (iStar DH734, Andor Inc.). The spectrograph and detection system's spectral range is between 200 and $850 \mathrm{~nm}$ with $0.08 \mathrm{~nm}$ resolution at $400 \mathrm{~nm}$. Wavelength calibration of the spectrograph was done by using a $\mathrm{Hg}-\mathrm{Ar}$ spectral calibration lamp. The detector gain was usually kept around 150 and the acquisition parameters of the detector delay time, $\left(t_{d}\right)$, and gate time, $\left(t_{\mathrm{g}}\right)$, were optimized for each element, seperately.

\subsection{Standards and reagents}

Aqueous stock solutions ( $1000 \mathrm{mg} / \mathrm{L}$ ) have been prepared by dissolving appropriate amounts of analytical grade solids from their chloride or nitrate salts in ultrapure water. Standard solutions have been prepared fresh by dilution with ultrapure water from the stock solutions. The nitrogen gas used to purge sample from the nebulizer to naphion membrane dryer has been obtained from a nitrogen generator (NitroLab), at 98\% purity. For real sample analysis, River Water Reference Material for Trace Metal (SLRS-4, NRC, Canada), Trace Metals in Drinking Water Standard (CRM-TMDW-A, High-Purity Standard) and bottled drinking water obtained from the local market (Spring water, Aydin) have been used.

\section{Results and discussion}

Before performing quantitative analysis of metal aerosols, the experimental and instrumental parameters that are known to affect the analytical performance of the LIBS system were studied. The experimental parameters regarding the aerosol generation are carrier gas flow rate and drying gas flow rate. The effects of laser pulse energy, detector gating parameters (delay time and gate time) and detector gain were considered as instrumental parameters. For characterization of the aerosols, particle size measurements were performed and the amount of sample transferred into the sample cell was estimated from the measurement of the sample volume left inside the nebulizer after running for a certain period of time.
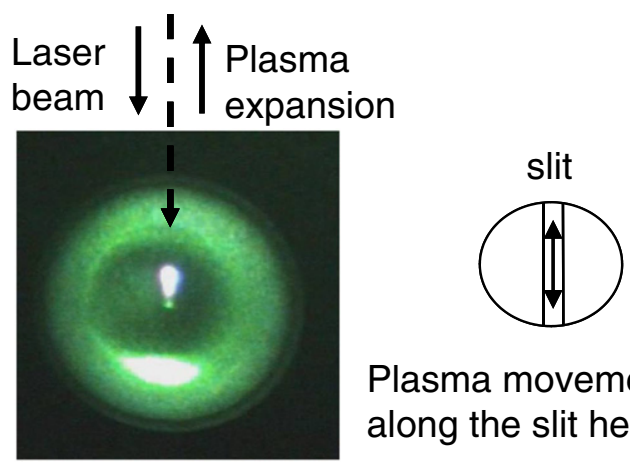

Plasma movement along the slit height

Fig. 3. A picture of the laser plasma and its direction of movement along the slit height.

\subsection{Experimental parameters}

\subsubsection{Sample flow rate}

The sample flow rate is the actual gas flow rate applied from the side port of the nebulizer at the top of the liquid level to transfer aerosol particles from the nebulizer to sample/plasma cell. Gas flow rate determines the number densities of the particles transported into the plasma cell. At low flow rates the transport efficiency of aerosols is low and at high flow rates, aerosols are transported to the plasma cell with no effective desolvation due to condensation. Therefore, metal aerosols generated inside the nebulizer were carried into the plasma cell by the flow of nitrogen gas at flow rates between $2.4 \mathrm{~L} / \mathrm{min}$ and $5.6 \mathrm{~L} / \mathrm{min}$.

Fig. 4 shows the effect of carrier gas flow rate on LIBS signal strength for $\mathrm{Na}, \mathrm{Mg}$ and $\mathrm{Ca}$ aerosols. As can be seen from the figure, the signal strength for $\mathrm{Na}$ and $\mathrm{Mg}$ steadily increases up to $4.8 \mathrm{~L} / \mathrm{min}$ then decreases and stays almost the same with increasing gas flow rate. However, $\mathrm{Ca}$ (II) emission shows an almost independent behavior with respect to changes in gas flow rate. A decrease in signal intensity for $\mathrm{Na}$ and $\mathrm{Mg}$ at high flow rates can mostly be attributed to the dilution of the sample in carrier gas. Condensation of aerosols inside the plasma cell is also another factor in the observation of reduced signal intensity. Therefore, flow rates at which maximum signal is obtained were selected as optimum flow rate and used throughout the experiments.

\subsubsection{Drying gas flow rate}

Drying gas flow rate is the amount of gas flowing from the outside walls of the membrane dryer in opposite direction with respect to the sample flow. The drying gas flow rate should be kept below the sample flow rate in order to permit water vapors to diffuse out of the membrane walls. Otherwise, excess gas pressure causes the membrane to shrivel and drying process may not be effectively achieved. A drying gas flow rate of $3.5 \mathrm{~L} / \mathrm{min}$ has been used for most of the experiments.

\subsection{Instrumental parameters}

\subsubsection{Laser pulse energy and detector gating parameters}

Optimization of the LIBS signal with respect to laser pulse energy was performed between 20 and $150 \mathrm{~mJ} /$ pulse energy ranges. Laser energy dependent variations of signal intensity for $\mathrm{Na}, \mathrm{K}, \mathrm{Mg}$ and $\mathrm{Ca}$ were given in Fig. 5.

Laser pulses with energies between 20 and $150 \mathrm{~mJ}$ interact with metal aerosols that are introduced into the sample/plasma cell by continuous nebulization at around $4.0 \mathrm{~L} / \mathrm{min}_{2}$ gas flow. In general, for all the elements, signal intensity increases as the laser pulse energy increases. $\mathrm{Mg}$ (II) emission signal at $279.6 \mathrm{~nm}$ shows an almost linear increase with laser pulse energy up to $120 \mathrm{~mJ}$, indicating that the $\mathrm{Mg}$ plasma is optically thin within this energy regime. However, atomic

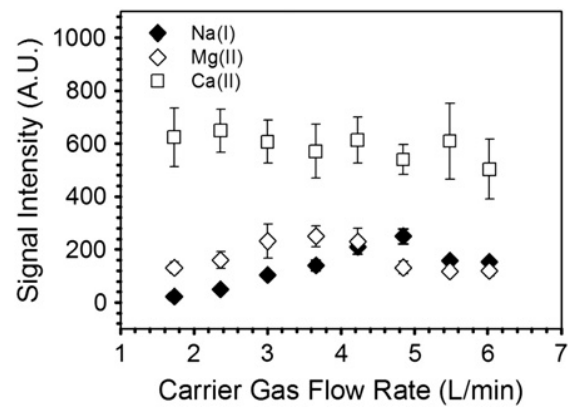

Fig. 4. Effect of nebulizer gas flow rate on $\mathrm{Na}$ (I) $589.0 \mathrm{~nm}, \mathrm{Mg}$ (II) $279.6 \mathrm{~nm}$ and $\mathrm{Ca}$ (II) $393.4 \mathrm{~nm}$ signal intensity. Laser energy of $45 \mathrm{~mJ} /$ pulse for $\mathrm{Na}, 55 \mathrm{~mJ} /$ pulse for Ca and $60 \mathrm{~mJ} /$ pulse for Mg was used. 

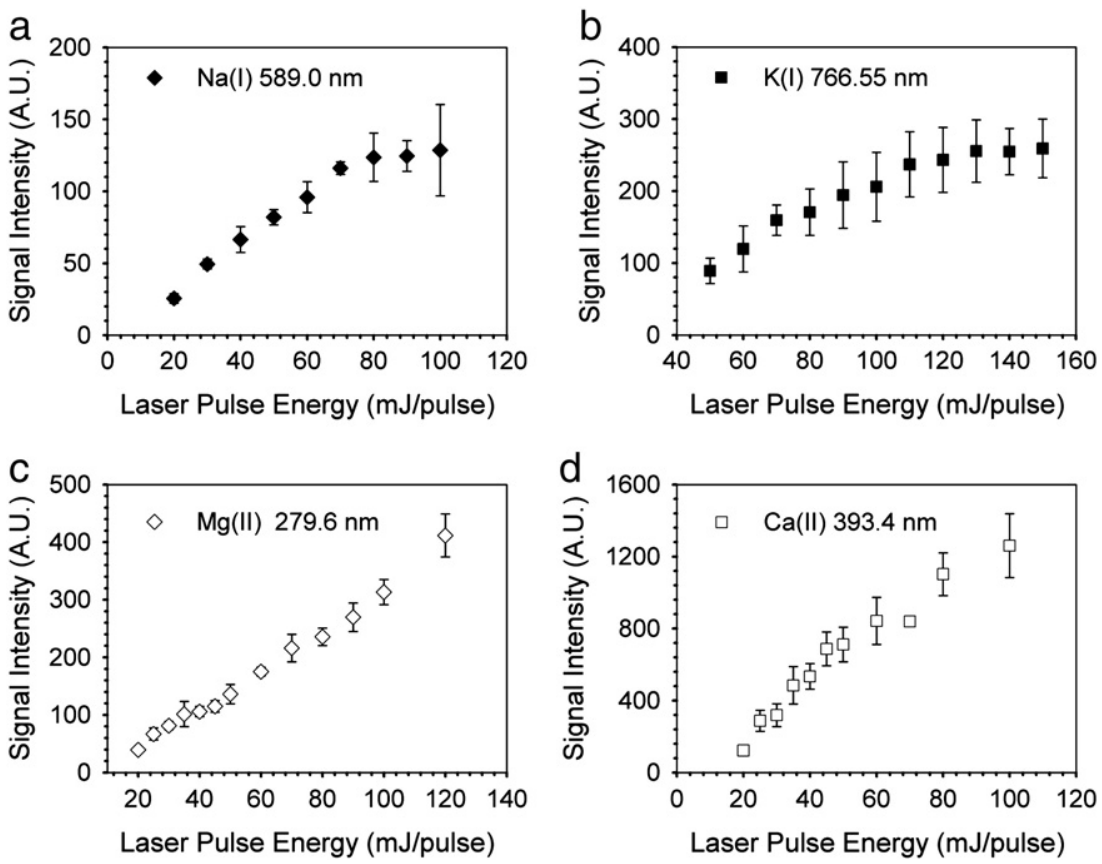

Fig. 5. Effect of laser energy on $\mathrm{Na}(\mathrm{I}) 589.0 \mathrm{~nm}, \mathrm{~K}(\mathrm{I}) 766.55 \mathrm{~nm}, \mathrm{Mg}$ (II) $279.6 \mathrm{~nm}$ and Ca(II) $393.4 \mathrm{~nm}$ signal intensity.

emissions from $\mathrm{Na}$, $\mathrm{K}$ and Ca plasma at their resonance transition wavelengths, deviate from the linearity after 70, 110 and $60 \mathrm{~mJ} /$ pulse laser energy, respectively. Departures from the linearity for $\mathrm{Na}, \mathrm{K}$ and $\mathrm{Ca}$ could be attributed to self absorption of the resonance lines.

For quantitative measurements laser energies at which maximum emission signal is observed in the linear range were used. Therefore LIBS spectra were recorded at different laser energies for different elements.

Transient nature of the laser plasma requires time resolution experiments to be performed. Therefore, detector delay time and gate time parameters at which maximum LIBS signal is obtained were studied for every element under consideration. Table 1 summarizes optimum detector gating parameters.

\subsection{Representative spectra}

Representative 10 shot accumulation spectra acquired from the plasmas obtained from $\mathrm{Zn}, \mathrm{Pb}, \mathrm{Cu}, \mathrm{Cr}, \mathrm{Cd}$ and $\mathrm{Al}$ aerosols under optimum experimental conditions are given in Fig. 6. For each spectrum, resonance line emission signals at which quantitative measurements were performed, are clearly presented as an inset. In addition to atomic emission lines of the metal under consideration, strong emission lines from nitrogen, $\mathrm{N}(\mathrm{I})$ at $742.4 \mathrm{~nm}, 744.3 \mathrm{~nm}, 746.8 \mathrm{~nm}$ and $821.6 \mathrm{~nm}$, hydrogen, $\mathrm{H}(\mathrm{I})$ at $656.3 \mathrm{~nm}$ and oxygen, $\mathrm{O}(\mathrm{I})$ at $777.2 \mathrm{~nm}$ were observed. Nitrogen lines are most probably originating from the carrier gas, and hydrogen and oxygen lines are from the presence of water vapor inside the plasma cell.

\subsection{Aerosol characterization}

The average diameter of aerosol droplets produced in ultrasonic nebulization sample introduction systems, typically range between 1 and $20 \mu \mathrm{m}$. However, most of the droplets with larger sizes are removed during their transport from the nebulizer to the atomization cell. Only the smaller droplets can reach the atomization chamber. In this study, the particle size of the aerosols produced from the ultrasonic nebulizer was determined by particle size analyzer, Malvern MasterSizer HD-2000, with and without the membrane drying unit in place. In order to perform particle size measurements, the sample introduction unit was directly connected to a particle size analyzer

Table 1

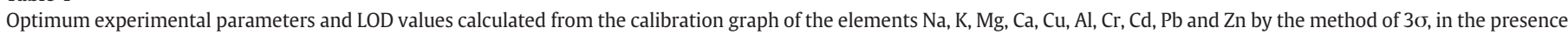
and absence of membrane dryer.

\begin{tabular}{|c|c|c|c|c|c|c|c|c|c|c|}
\hline \multirow[t]{3}{*}{ Element wavelength } & \multirow[t]{3}{*}{ LE mJ } & \multirow[t]{3}{*}{$\mathrm{T}_{\mathrm{d}}(\mu \mathrm{s})$} & \multirow[t]{3}{*}{$\mathrm{t}_{\mathrm{g}}(\mathrm{ms})$} & \multirow[t]{3}{*}{ Pulses accum. } & \multirow[t]{3}{*}{ Gain } & \multirow[t]{3}{*}{ Flow rate $(\mathrm{L} / \mathrm{min})$} & \multicolumn{4}{|c|}{ LOD $(\mathrm{mg} / \mathrm{L})$} \\
\hline & & & & & & & \multicolumn{2}{|l|}{ Dryer } & \multicolumn{2}{|c|}{ Literature } \\
\hline & & & & & & & $\mathrm{W} / \mathrm{O}$ & W & Ref. $[4]^{*}$ & Ref. [24]* \\
\hline $\mathrm{Na}(\mathrm{I}) 589.0 \mathrm{~nm}$ & 45 & 4 & 1 & 10 & 150 & 3.6 & 1.8 & 0.45 & 0.5 & 0.08 \\
\hline $\mathrm{K}(\mathrm{I}) 766.55 \mathrm{~nm}$ & 120 & 3 & 0.5 & 10 & 150 & 1.7 & 7.7 & 6.01 & - & 4 \\
\hline $\mathrm{Ca}(\mathrm{II}) 393.4 \mathrm{~nm}$ & 60 & 1 & 1 & 10 & 100 & 4.2 & 1.4 & 1.83 & 0.3 & 0.6 \\
\hline $\mathrm{Mg}$ (II) $279.6 \mathrm{~nm}$ & 80 & 0.6 & 1 & 10 & 100 & 4.2 & 1.0 & 1.85 & 1 & 3 \\
\hline $\mathrm{Cu}(\mathrm{I}) 324.75 \mathrm{~nm}$ & 140 & 9 & 0.5 & 10 & 150 & 3.0 & 1.7 & 1.99 & 7 & 5 \\
\hline $\mathrm{Zn}(\mathrm{I}) 481.05 \mathrm{~nm}$ & 150 & 8 & 0.75 & 10 & 150 & 3.0 & 54.3 & 41.64 & 120 & - \\
\hline $\mathrm{Al}(\mathrm{I}) 396.15 \mathrm{~nm}$ & 130 & 10 & 0.075 & 10 & 150 & 3.0 & 2.7 & 6.47 & 10 & 18 \\
\hline $\mathrm{Cr}$ (II) $283.56 \mathrm{~nm}$ & 130 & 0.7 & 0.075 & 10 & 150 & 3.0 & 5.4 & 6.49 & 10 & 200 \\
\hline $\mathrm{Pb}(\mathrm{I}) 405.8 \mathrm{~nm}$ & 150 & 6.5 & 0.1 & 10 & 150 & 3.0 & 50.2 & 13.6 & 100 & 40 \\
\hline Cd(II) $226.5 \mathrm{~nm}$ & 130 & 0.5 & 1 & 10 & 150 & 3.0 & 82.3 & 43.99 & - & - \\
\hline
\end{tabular}

\footnotetext{
* LODs from Refs. [4] and [24] were obtained from the same experimental conditions for all elements.
} 

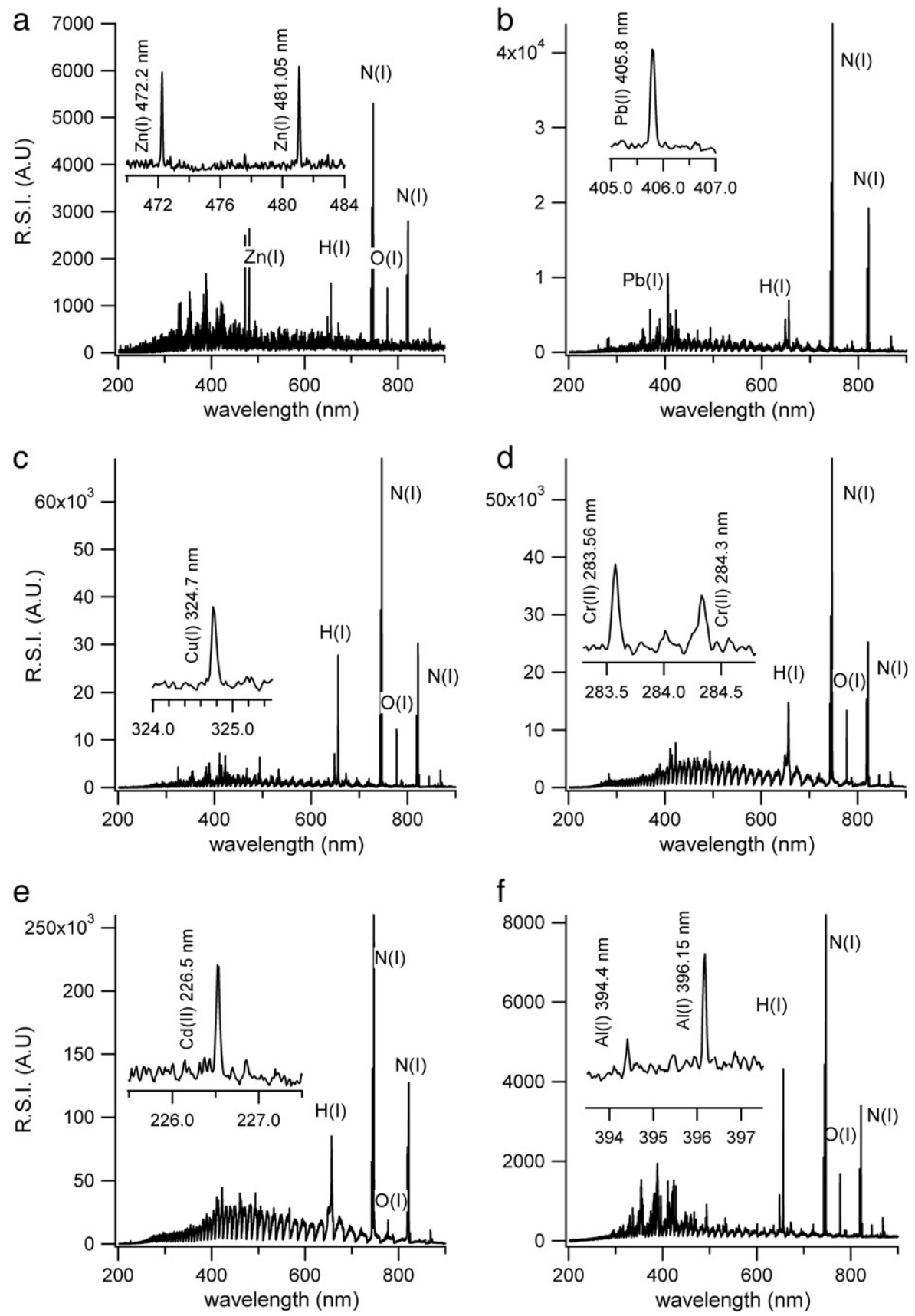

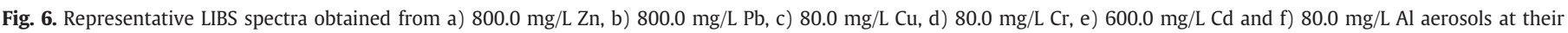
optimum experimental conditions.

instrument. The size of the aerosols produced by ultrasonic nebulization of $100 \mathrm{mg} / \mathrm{L}$ aqueous $\mathrm{Na}$ solution (from $\mathrm{NaCl}$ ) right after the desolvation unit, in the absence of membrane dryer, was measured as $1.5 \mu \mathrm{m}$ in diameter, $\left(\mathrm{d}_{90}\right)$. When the membrane dryer is connected, the size of the aerosols was decreased to $0.5 \mu \mathrm{m},\left(\mathrm{d}_{90}\right)$. This ensures removal of excess moisture from the aerosol droplets by the naphion membrane dryer and hence the particle size of the aerosols decreases. Spectroscopic data related with the effect of membrane dryer on LIBS signal intensity is given in the following sections.

In order to quantify the amount of sample transported into the sample cell, the transport efficiency of the nebulizer at optimum flow rates was determined. For this purpose, some amount of a sample was placed inside the nebulizer and allowed to flow for a specific period of time. The amount of sample solution left inside the nebulizer and the one collected in the waste were measured. The amount of sample transported into the sample cell at optimum flow rate has been quantified from the difference by calculation as $0.14 \mathrm{~g} / \mathrm{min}$. This amount corresponds to $23 \mathrm{pg}$ of sodium aerosols travelling through total volume of the plasma cell (approx. $20 \mathrm{~cm}^{3}$ ) during $10 \mathrm{~ns}$ pulse duration of the laser. When one considers a few millimeter cubes of plasma volume, this number can be roughly estimated as a few femtograms.

\subsection{Effect of membrane dryer}

The naphion membrane dryer is selective to moisture content of the sample flowing through. Metal aerosols were dried by a counter-current flow of a membrane drying gas. The effect of using membrane dryer on signal strength of $\mathrm{Pb}(\mathrm{I})$ at $363.95 \mathrm{~nm}, 368.34 \mathrm{~nm}$ and $405.8 \mathrm{~nm}$ and also $\mathrm{H}(\mathrm{I})$ at 656.3 is presented in Fig. 7. Solid lines represent signal in the presence of membrane dryer and dotted 
lines present signal without a dryer. As can be seen from the figure that use of membrane dryer has significantly increased analyte emission signal from $\mathrm{Pb}(\mathrm{I})$, for all the wavelengths with an enhancement factor of about three whereas $\mathrm{H}_{\alpha}$ emission at $656.3 \mathrm{~nm}$ significantly decreased due to effective removal of water content.

\subsection{Quantitative analysis}

\subsubsection{Calibration graphs and LOD determination}

A set of calibration standards with known concentrations of $\mathrm{Na}$, $\mathrm{K}, \mathrm{Mg}, \mathrm{Ca}, \mathrm{Cu}, \mathrm{Al}, \mathrm{Cr}, \mathrm{Cd}, \mathrm{Pb}$ and $\mathrm{Zn}$ was prepared from their stock solutions and LIBS signal was recorded in order to relate analytical response with analyte concentration. Data is obtained from 10 shot accumulation of 5 replicate measurements with detector gain of 150 . Relative signal intensity values were obtained from the peak area of atomic lines after background emission was subtracted. For all the elements studied, calibration curves constructed from their respective LIBS measurements were presented in Fig. 8.

As can be seen from the figure that, calibration curves are linear over a range of concentrations, with regression constants higher than 0.97 . Detection limits, $\left(C_{m}\right)$, for each element in terms of solution concentration was also determined from the well-known formula, $C_{m}=\frac{k * \sigma_{B G}}{m}$, where $\sigma_{B G}$ is the standard deviation of the background, $m$ is the slope of the calibration curve and $k$ is the constant with varying degrees of confidence level. The value $k=3$ with $95 \%$ confidence level of detection was used throughout the calculations.

In order to evaluate the effect of membrane dryer on LIBS sensitivity, the detection limit calculations were performed on LIBS data taken in the presence and absence of a membrane dryer for all the elements under consideration. A list of LOD values are given in Table 1.

In general, LOD values for ten different elements range from $0.45 \mathrm{mg} / \mathrm{L}$ to $43.99 \mathrm{mg} / \mathrm{L}$ and LOD values obtained for $\mathrm{Na}, \mathrm{K}, \mathrm{Zn}, \mathrm{Pb}$ and $\mathrm{Cd}$ are noticeably better in the presence of membrane dryer. Four and two times enhancement factors were obtained for $\mathrm{Pb}$ and $\mathrm{Cd}$, respectively. $\mathrm{Ca}, \mathrm{Mg}$ and $\mathrm{Cu}$ present comparable results with the ones obtained in the absence of a membrane dryer while LOD values obtained for $\mathrm{Al}$ and $\mathrm{Cr}$ did not show any improvement. The last two columns in Table 1 present LOD data from the literature in which LIBS analysis was performed in bulk liquid [4] and in liquid-jet [24] experiments. When LOD concentrations obtained from this study are compared to that of the literature [4,24], no improvements in LOD values were observed for easily ionizable elements like, $\mathrm{Na}, \mathrm{K}$ and $\mathrm{Ca}$, however, ultrasonic nebulization sample introduction system with membrane dryer unit presented in this work provided some enhancement in $\mathrm{LOD}$ values for $\mathrm{Cu}, \mathrm{Zn}, \mathrm{Cr}, \mathrm{Al}$ and $\mathrm{Pb}$ elements. The literature studies mentioned above do not contain any result for the highly toxic element of Cd, however, $500 \mathrm{mg} / \mathrm{L} \mathrm{LOD}$ value for Cd was reported in another work [2].

Another study [8] in the literature lists LOD values of $0.4 \mathrm{ppm}$ for $\mathrm{Cr}$ and $0.1 \mathrm{ppm}$ for $\mathrm{Mg}$ from the liquid-jet experiments under optimized instrumental conditions and with the use of relatively higher laser pulse energies of $200 \mathrm{~mJ}$. For comparison, $1.0 \mathrm{ppm}$ LOD result presented in our study for $\mathrm{Mg}$ was obtained at $80 \mathrm{~mJ} /$ pulse laser energy and signal intensity increased linearly with respect to increase in laser pulse energy, as is given in Fig. 5(c), contrary to $\mathrm{Na}$, $\mathrm{K}$ and $\mathrm{Ca}$ cases. It is expected that improvements in LOD values for Mg may be obtained by utilizing higher laser pulse energy.

\subsubsection{Real water samples analysis}

In order to investigate the applicability of the LIBS system to real water analysis, river water standard, SLRS-4, drinking water standard, CRM-TMDW-A and bottled drinking water obtained from a local store were utilized. $\mathrm{Na}, \mathrm{Ca}$, and $\mathrm{Mg}$ content present in real samples were determined under optimum conditions. For this purpose, at least three calibration standards for each element were run through the system followed by the real water samples and analyte signals were recorded. Concentrations of elements present in real water samples were obtained from their respective calibration graphs. Here, the time spend is mostly for performing the calibration analysis and it takes only a minute for one sample analysis with $1 \mathrm{~ms}$ detector gating time after calibration is performed. The total sampling time for the analysis of three elements in one sample can be 15-20 min including calibrations. Table 2 presents data from these experiments. For all types of standard water samples, measured values are in good agreement with reference values, except for magnesium. Magnesium concentration present in river water sample was below the detection limit of our system, therefore could not be detected. For the case of drinking water standard, the measured value for magnesium was excessively higher than the reference value after several trials. However, the magnesium amount present in bottled water could be detected with a better accuracy.

Spike and recovery experiments [28] are important tools for validating and assessing the accuracy of the analytical technique. A known quantity of analyte is added to a sample to test if the response of the method to a sample is the same as the one obtained from a calibration curve. In this study, since the amounts of $\mathrm{K}, \mathrm{Al}, \mathrm{Cu}, \mathrm{Cr}$ and $\mathrm{Zn}$ in real water samples are lower than the minimum detectable
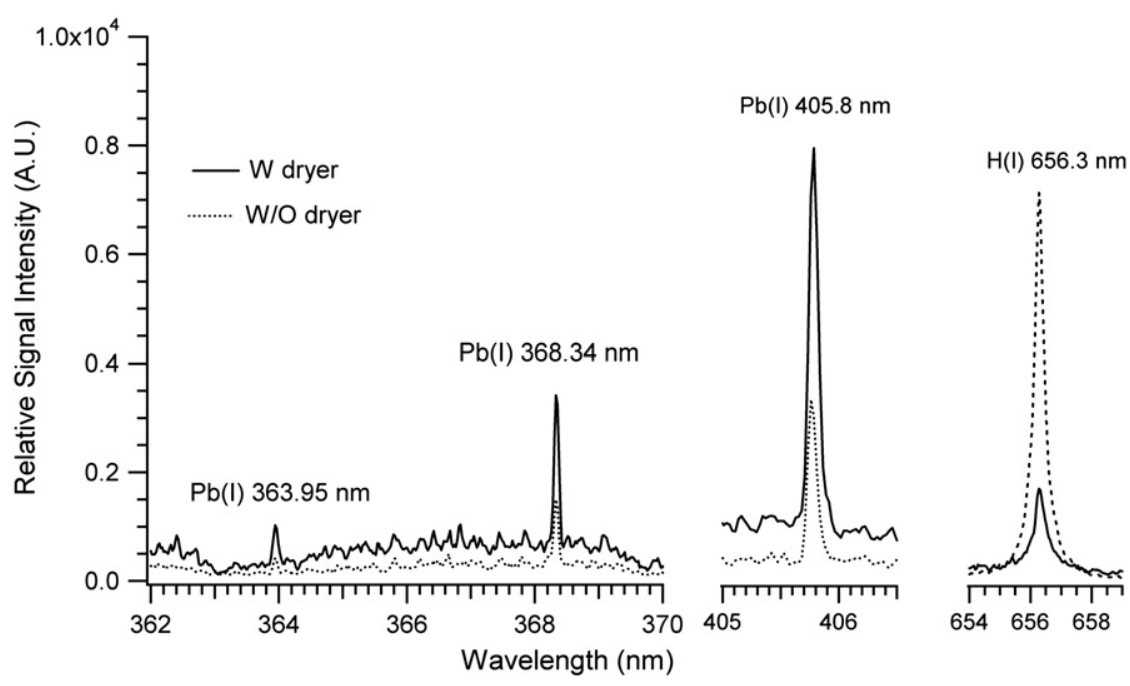

Fig. 7. Analyte signal enhancement when membrane dryer is used. 

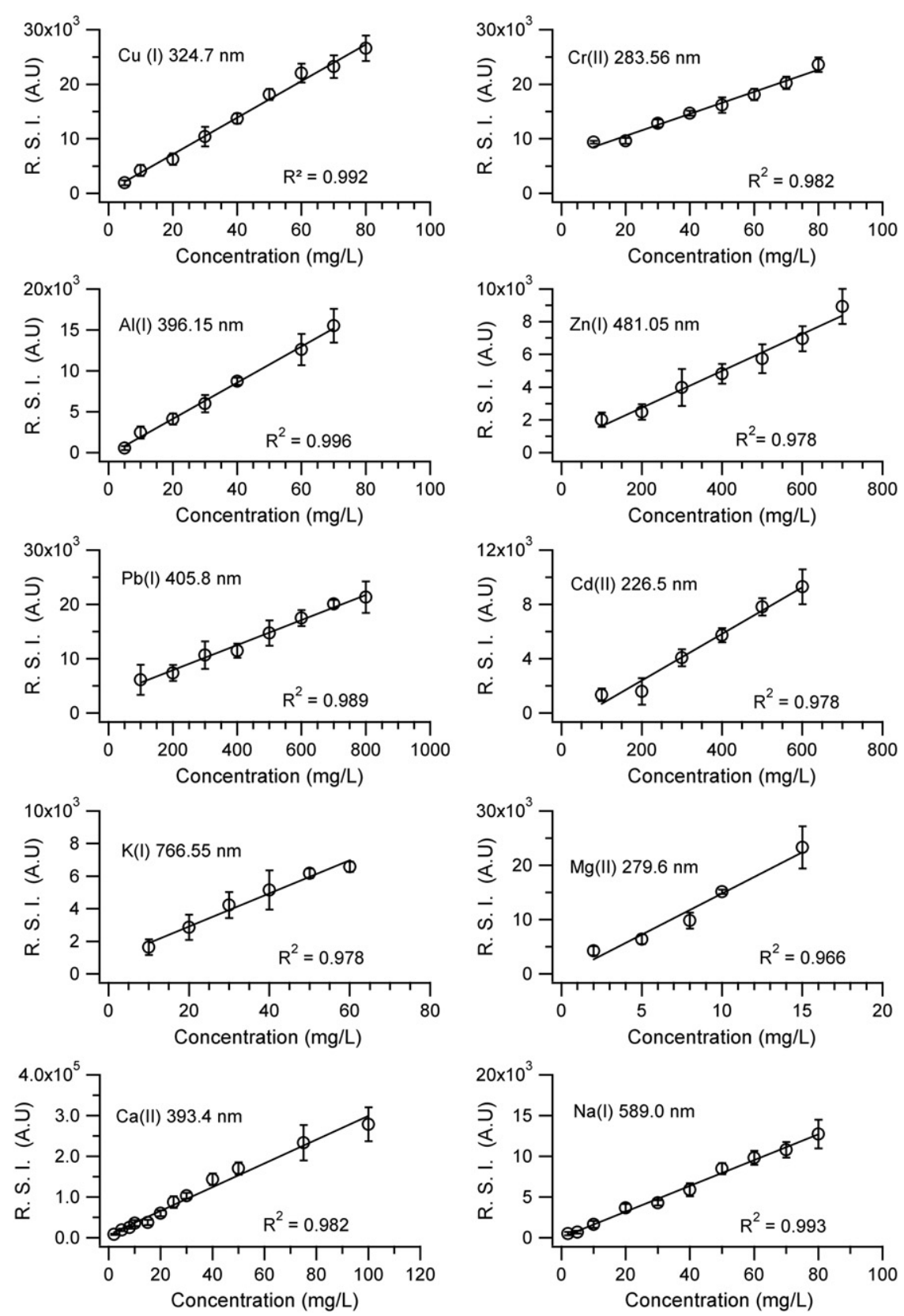

Fig. 8. Calibration graphs for $\mathrm{Cu}, \mathrm{Cr}, \mathrm{Al}, \mathrm{Zn}, \mathrm{Pb}, \mathrm{Cd}, \mathrm{K}, \mathrm{Mg}$, $\mathrm{Ca}$ and $\mathrm{Na}$ using ultrasonic nebulization sample introduction system with a membrane dryer.

concentrations, the validity of the method was tested through spiking experiments. For this purpose river water standard, SLRS-4, and bottled drinking water sample were spiked with known amount of analyte and the LIBS response of the resulting solution were measured. Results obtained from the spiking experiments are listed in Table 3. As can be seen from the table, there is a good correlation between expected and observed values with relatively high degree of recoveries.

\section{Conclusions}

A sample introduction system consisting of an USN and a tandem heater-condenser-membrane dryer unit for laser-induced breakdown spectroscopic detection of metal aerosols has been realized. Optimization of the LIBS signal with respect to sample flow rate, laser energy and detector timing parameters were performed. The use of membrane

Table 2

$\mathrm{Na}, \mathrm{Ca}$, and $\mathrm{Mg}$ content in real water samples.

\begin{tabular}{|c|c|c|c|c|c|c|}
\hline \multirow[t]{2}{*}{ Element } & \multicolumn{2}{|c|}{ SLRS-4 river water std. } & \multicolumn{2}{|c|}{ CRM-TMDW-A drinking water std. } & \multicolumn{2}{|c|}{ Bottled drinking water } \\
\hline & $\begin{array}{l}\text { Reference value } \\
(\mathrm{mg} / \mathrm{L})\end{array}$ & $\begin{array}{l}\text { Measured value } \\
(\mathrm{mg} / \mathrm{L})\end{array}$ & $\begin{array}{l}\text { Reference value } \\
(\mathrm{mg} / \mathrm{L})\end{array}$ & $\begin{array}{l}\text { Measured value } \\
(\mathrm{mg} / \mathrm{L})\end{array}$ & $\begin{array}{l}\text { Reference value } \\
(\mathrm{mg} / \mathrm{L})\end{array}$ & $\begin{array}{l}\text { Measured value } \\
(\mathrm{mg} / \mathrm{L})\end{array}$ \\
\hline $\mathrm{Na}(\mathrm{I}) 589.0 \mathrm{~nm}$ & $2.4 \pm 0.2$ & $1.7 \pm 1.2$ & $2.3 \pm 0.01$ & $2.7 \pm 0.1$ & 6.3 & $6.2 \pm 2.5$ \\
\hline $\mathrm{Ca}(\mathrm{II}) 393.4 \mathrm{~nm}$ & $6.2 \pm 0.2$ & $6.8 \pm 2.0$ & $31.0 \pm 0.2$ & $27.8 \pm 4.7$ & 6.0 & $6.1 \pm 1.3$ \\
\hline $\operatorname{Mg}(\mathrm{II}) 279.6 \mathrm{~nm}$ & $1.6 \pm 0.1$ & $\mathrm{ND}^{*}$ & $8.0 \pm 0.04$ & $20.3 \pm 6.2$ & 2.2 & $1.6 \pm 0.5$ \\
\hline
\end{tabular}

* ND: not detected. 
Table 3

Recovery results from real water samples spiked with standards.

\begin{tabular}{|c|c|c|c|c|c|c|}
\hline \multirow[t]{2}{*}{ Elements } & \multicolumn{3}{|c|}{ SLRS-4 river water std. } & \multicolumn{3}{|c|}{ Bottled drinking water } \\
\hline & Expected (mg/L) & Observed (mg/L) & Recovery \% & Expected (mg/L) & Observed (mg/L) & Recovery \% \\
\hline $\mathrm{K}(\mathrm{I}) 766.55 \mathrm{~nm}$ & 30.68 & $31.9 \pm 11.6$ & $104.0 \pm 37.9$ & 32.0 & $25.5 \pm 7.8$ & $79.7 \pm 24.4$ \\
\hline $\mathrm{Al}(\mathrm{I}) 396.15 \mathrm{~nm}$ & 50.0 & $54.4 \pm 18.6$ & $108.7 \pm 37.3$ & 50.1 & $50.7 \pm 4.8$ & $101.4 \pm 9.6$ \\
\hline $\mathrm{Cu}(\mathrm{I}) 324.7 \mathrm{~nm}$ & 30.0 & $29.7 \pm 7.4$ & $99 \pm 24.8$ & 30.0 & $29.5 \pm 5.3$ & $98.5 \pm 17.7$ \\
\hline $\mathrm{Cr}$ (II) $283.56 \mathrm{~nm}$ & 50.0 & $59.4 \pm 25.1$ & $118.8 \pm 40.9$ & 50.0 & $57.4 \pm 11.5$ & $114.9 \pm 19.9$ \\
\hline $\mathrm{Zn}(\mathrm{I}) 481.05 \mathrm{~nm}$ & 500.0 & $512.1 \pm 38.6$ & $102.4 \pm 7.7$ & 500.0 & $574.4 \pm 33.5$ & $115.1 \pm 6.7$ \\
\hline
\end{tabular}

${ }^{*}$ Spiked concentrations for $\mathrm{K}$ and $\mathrm{Cu}$ is $30.0 \mathrm{mg} / \mathrm{L}$, for $\mathrm{Al}$ and $\mathrm{Cr}$ is $50.0 \mathrm{mg} / \mathrm{L}$ and for $\mathrm{Zn}$ is $500 \mathrm{mg} / \mathrm{L}$.

dryer after the desolvation unit has provided enhancement in signal intensity for some of the elements studied and especially for $\mathrm{Cd}(\mathrm{I})$ and $\mathrm{Pb}(\mathrm{I})$, two to three times enhancements in LOD values were obtained. Detection limits obtained for all the elements are either better or comparable to the current literature values. Especially for elements $\mathrm{Mg}$, $\mathrm{Cu}, \mathrm{Zn}, \mathrm{Al}, \mathrm{Cr}$ and $\mathrm{Pb}$ the LOD values were found to be relatively lower than the current values. Percent recovery values obtained through spiking experiments are noticeably high for each element under consideration. The system described here enables direct and continuous determination of $\mathrm{Na}, \mathrm{K}, \mathrm{Mg}, \mathrm{Ca}, \mathrm{Cu}, \mathrm{Al}, \mathrm{Cr}, \mathrm{Cd}, \mathrm{Pb}$ and $\mathrm{Zn}$ concentrations in aqueous environments. Further efforts to be performed on reducing the size and energy consumption of the system presented here will facilitate building a LIBS field instrument for on-site determination of environmental pollutants in aqueous systems.

\section{Acknowledgments}

Authors thank the Izmir Institute of Technology, IYTE and the Scientific and Technological Research Council of Turkey, TÜBITTAK, for their financial support through research projects: BAP-12, $108 \mathrm{~T} 376$ and 109T327. Special thanks to Prof. Dr. Hurriyet Polat for her generous help in particle size measurements.

\section{References}

[1] D.A. Cremers, L.J. Radziemski, T.R. Loree, Spectrochemical analysis of liquids using the laser spark, Appl. Spectrosc. 38 (1984) 721-729.

[2] R. Knopp, F.J. Scherbaum, J.I. Kim, Laser induced breakdown spectroscopy (LIBS) as an analytical tool for the detection of metal ions in aqueous solutions, Fresenius J. Anal. Chem. 355 (1996) 16-20.

[3] J.R. Wachter, D.A. Cremers, Determination of uranium in solution using laser-induced breakdown spectroscopy, Appl. Spectrosc. 41 (1987) 1042-1048.

[4] P. Fichet, P. Mauchien, J.F. Wagner, C. Moulin, Quantitative elemental determination in water and oil by laser induced breakdown spectrometry, Anal. Chim. Acta 429 (2001) 269-278.

[5] H.A. Archontaki, S.R. Crouch, Evaluation of an isolated droplet sample introduction system for laser-induced breakdown spectroscopy, Appl. Spectrosc. 42 (1988) 741-746.

[6] C. Janzen, R. Fleige, R. Noll, H. Schwenke, W. Lahmann, J. Knoth, P. Beaven, E. Jantzen, A. Oest, P. Koke, Analysis of small droplets with a new detector for liquid chromatography based on laser-induced breakdown spectroscopy, Spectrochim. Acta Part B 60 (2005) 993-1001.

[7] W.F. Ho, C.W. Ng, N.H. Cheung, Spectrochemical analysis of liquids using laser induced plasma emission: effects of laser wavelength, Appl. Spectrosc. 51 (1997) 87-91.

[8] F.Y. Yueh, R.C. Sharma, J.P. Singh, H.S. Zhang, W.A. Spencer, J. Air Waste Manage. Assoc. 52 (2002) 1307-1315.

[9] S. Koch, R. Court, W. Garen, W. Neu, R. Reuter, Detection of manganese in cavitation bubbles using laser induced breakdown spectroscopy, Spectrochim. Acta Part B 60 (2005) 1230-1235.
[10] W. Pearman, J. Scaffidi, S.M. Angel, Dual-pulse laser-induced breakdown spectroscopy in bulk aqueous solution with an orthogonal beam geometry, Appl. Opt. 42 (2003) 6085-6093.

[11] M. Lawrence-Snyder, J. Scaffidi, S.M. Angel, A.P.M. Michel, A.D. Chave Sequential-pulse laser-induced breakdown spectroscopy of high-pressure bulk aqueous solutions, Appl. Spectrosc. 61 (2007) 171.

[12] V. Lazic, S. Jovicevic, R. Fantoni, F. Colao, Efficient plasma and bubble generation underwater by an optimized laser excitation and its application for liquid analyses by laser-induced breakdown spectroscopy, Spectrochim. Acta Part B 62 (2007) 1433-1442.

[13] L.J. Radziemski, T.R. Loree, D.A. Cremers, N.M. Hoffman, Time-resolved laser induced breakdown spectrometry of aerosols, Anal. Chem. 55 (1983) 1246-1252.

[14] S. Yalcin, D.R. Crosley, G.P. Smith, G.W. Faris, Spectroscopic characterization of laser-produced plasmas for in-situ toxic metal monitoring, Hazard. Waste Hazard. Mater. 13 (1996) 51-61.

[15] J.E. Carranza, B.T. Fisher, G.D. Yoder, D.W. Hahn, On-line analysis of ambient air aerosols using laser induced breakdown spectroscopy, Spectrochim. Acta Part B 56 (2001) 851-864.

[16] M. Martin, M.D. Cheng, Detection of chromium aerosol using time-resolved laser induced plasma spectroscopy, Appl. Spectrosc. 54 (9) (2000) 1279-1285.

[17] D.W. Hahn, M.M. Lunden, Detection and analysis of aerosol particles by laser-induced breakdown spectroscopy, Aerosol Sci. Technol. 33 (2000) 30-48.

[18] J.S. Huang, K.C. Lin, Laser-induced breakdown spectroscopy of liquid droplets: correlation analysis with plasma-induced current versus continuum background, J. Anal. At. Spectrom. 20 (2005) 53-59.

[19] H. Zhang, F.Y. Yueh, J.P. Singh, Performance evaluation of laser-induced breakdown spectrometry as a multimetal continuous emission monitor, J. Air Waste Manage. Assoc. 51 (2001) 681-687.

[20] S. Unal, S. Yalcin, Development of a continuous flow hydride generation laser-induced breakdown spectroscopic system: determination of tin in aqueous environments, Spectrochim. Acta Part B 65 (2010) 750-757.

[21] J.P. Singh, H. Zhang, F. Yueh, K.P. Carney, Investigation of the effects of atmospheric conditions on the quantification of metal hydrides using laser induced breakdown spectroscopy, Appl. Spectrosc. 50 (1996) 764-773.

[22] J.B. Simeonsson, LJ. Williamson, Characterization of laser induced breakdown plasmas used for measurements of arsenic, antimony and selenium hydrides, Spectrochim. Acta Part B 66 (2011) 754-760.

[23] D.A. Rusak, B.C. Castle, B.W. Smith, J.D. Winefordner, Fundamentals and applications of laser induced breakdown spectroscopy, Crit. Rev. Anal. Chem. 27 (1997) 257-290.

[24] O. Samek, D.C.S. Bedows, J. Kaiser, S.V. Kukhlevsky, M. Liska, H.H. Telle, J. Young, Applications of laser-induced breakdown spectroscopy to in situ analysis of liquid samples, Opt. Eng. 39 (2000) 2248-2262.

[25] W.B. Lee, J. Wu, Y.I. Lee, J. Sneddon, Recent applications of laser-induced breakdown spectroscopy: a review of material approaches, Appl. Spectrosc. Rev. 39 (2004) 27-97.

[26] J.D. Winefordner, I.B. Gornushkin, T. Correll, E. Gibb, B.W. Smith, N. Omenetto Comparing several atomic spectrometric methods to the super stars: special emphasis on laser induced breakdown spectrometry, LIBS, a future super star, J. Anal. At. Spectrom. 19 (2004) 1061-1083.

[27] M. Essien, L.J. Radziemski, J. Sneddon, Detecetion of cadmium, lead and zinc in aerosols by laser-induced breakdown spectrometry, J. Anal. At. Spectrom. 3 (1988) 985-988.

[28] D.C. Harris, Quantitative Chemical Analysis, W.H. Freeman and Company, New York, 2007. 